\title{
Identifying natural and anthropogenically-induced geohazards from satellite ground motion and geospatial data: Stoke-on-Trent, UK
}

\author{
Hannah Jordan ${ }^{1 *}$, Francesca Cigna $^{2}$, Luke Bateson ${ }^{1}$ \\ ${ }^{1}$ British Geological Survey, Environmental Science Centre, Keyworth, Nottinghamshire, NG12 \\ 5GG, UK. Email: hann@bgs.ac.uk; lbateston@bgs.ac.uk. \\ ${ }^{2}$ Formerly at British Geological Survey, Environmental Science Centre, Keyworth, \\ Nottinghamshire, NG12 5GG, UK. Email: francesca.cigna@gmail.com. \\ *Corresponding author
}

\begin{abstract}
Determining the location and nature of hazardous ground motion resulting from natural and anthropogenic processes such as landslides, tectonic movement and mining is essential for hazard mitigation and sustainable resource use. Ground motion estimates from satellite ERS-1/2 persistent scatterer interferometry (PSI) were combined with geospatial data to identify areas of observed geohazards in Stoke-on-Trent, UK. This investigation was performed within the framework of the EC FP7-SPACE PanGeo project which aimed to provide free and open access to geohazard information for 52 urban areas across Europe. Geohazards identified within the city of Stoke-on-Trent and neighbouring rural areas are presented here alongside an examination of the PanGeo methodology.
\end{abstract}

A total of 14 areas experiencing ground instability caused by natural and anthropogenic processes have been defined, covering $122.35 \mathrm{~km}^{2}$. These are attributed to a range of geohazards, including landslides, ground dissolution, made ground and mining activities. The dominant geohazard (by area) is ground movement caused by post-mining groundwater recharge and mining-related subsidence (93.19\% of total geohazard area), followed by landsliding (5.81\%). Observed ground motions along the satellite line-of-sight reach maxima of $+35.23 \mathrm{~mm} / \mathrm{yr}$ and $-22.57 \mathrm{~mm} / \mathrm{yr}$. A combination of uplift, subsidence and downslope movement is displayed.

'Construction sites' and 'continuous urban fabric' (European Urban Atlas land use types) form the land uses most affected (by area) by ground motion and 'discontinuous very low density urban fabric' the least. Areas of 'continuous urban fabric' also show the highest average velocity towards the satellite $(5.08 \mathrm{~mm} / \mathrm{yr})$ and the highest PS densities (1262.92 points $/ \mathrm{km}^{2}$ ) along with one of the lowest standard deviations. Rural land uses tend to result in lower PS densities and higher standard deviations, a consequence of fewer suitable reflectors in these regions. PSI is also limited in its ability to identify especially rapid ground motion. As a consequence the supporting geospatial data proved especially useful for the identification of landslides and some areas of ground dissolution. The mapped areas of instability are also compared with modelled potential geohazards (the BGS GeoSure dataset). 


\section{Keywords}

Geohazard, persistent scatterer interferometry, ground instability, mapping.

\section{Introduction}

Ground instability may result in loss of life, injury, environmental damage and/or significant financial loss. Such instability is caused by a range of natural and anthropogenic processes (geohazards) including, for example, landslides, tectonic movement and mining.

Information on the location of the area disturbed, the nature of the geohazard and the rates and direction of ground movement is essential for hazard management and mitigation and the sustainable management of resources. However, this information is not always readily available because of the variable spatial extents of the processes, inaccessibility of some of the affected sites, complexity of the geohazards involved and operation of the processes over variable time-scales.

These data gaps combined with an increasing population density and changing weather conditions make geohazards research in the UK paramount. A spate of 165 landslides in 2012 resulted in 3 fatalities, 8 injuries and 3 train derailments (Pennington \& Harrison, 2013). Several soluble rock types are present in the UK and a range of hazardous karstic features have been identified (Cooper, Farrant \& Price, 2011). Volume changes in clays and mudstones in the southeast of the UK have resulted in costs of up to $f 500$ million in a single year (1991) (Jones \& Terrington, 2011). Additionally, groundwater recharge following the cessation of many UK mining activities has important implications for slope stability, pollution transport and water discharge (Bateson et al., 2015).

The European Commission Seventh Framework Programme Space Theme (EC FP7-SPACE) PanGeo project aimed to provide open access to ground instability information for 52 of the largest towns and cities across 27 European countries (http://www.pangeoproject.eu) and in some cases their neighbouring rural areas. Using a combination of satellite ground motion and geospatial data a range of geohazards were delineated and the findings disseminated as GIS layers and accompanying reports. Areas affected by deep ground motions, natural ground instability, natural ground movement and man-made (anthropogenically-induced) ground instability were identified. A total of approximately 10 $000 \mathrm{~km}^{2}$ across the 52 cities was affected, equating to $20 \%$ of the total area examined and exposing nearly 32.5 million people (Capes \& Teeuw, 2017). Stoke-on-Trent (Jordan et al., 2013) and London (Cigna et al., 2014) were selected as targets for the UK and the British Geological Survey (BGS) led the investigation of these areas.

Ground motion data derived from satellite synthetic aperture radar (SAR) imagery have proved invaluable for characterising hazardous ground instability both in the UK (e.g. Banton et al., 2013; Sowter et al., 2013) and internationally (e.g. Cuenca et al., 2013; Wasowski \& Bovenga, 2015; Zhu et al., 2015). In contrast to the more traditional techniques, satellite-derived ground motion data typically cover larger areas, have a higher measurement frequency and achieve greater accuracies (Crosetto et al., 2008). As a result, they can be used to capture information on a range of natural and anthropogenic geohazards as well as detecting motion from multiple hazards in the same dataset (Cigna et al., 2014). Persistent scatterer interferometry is used in the current study as it relies upon a time series of radar acquisitions to identify objects whose scattering properties remain 
stable over time. This favours the detection of motion of the ground itself rather than that of localised motions within the structure of buildings; the development of individual structures and/ or; atmospheric effects.

This paper presents the results of the PanGeo project geohazard mapping for the city of Stoke-on-Trent, UK and its neighbouring, more rural areas. The available satellite and geospatial input data for the study area are described and the PanGeo methodology is outlined. Geohazards identified within the region are presented and detailed case studies are provided for a selection of the observed ground motion areas. The mapped areas of instability are compared with modelled potential geohazards from the BGS GeoSure dataset. The potential of the combined PSI and geospatial data methodology to accurately delineate ground instability caused by a range of geohazards is also assessed.

\section{Study site}

The study site $\left(1,394 \mathrm{~km}^{2}\right)$ is centred upon the city of Stoke-on-Trent and includes neighbouring rural areas in the English counties of Staffordshire, Cheshire and Shropshire (Figure 1). The north-eastern portion of the study area lies within the Peak District National Park. The study site was chosen as result of data availability and a well-documented industrial history: the resulting area corresponds to the persistent scatterer (PS) and land use (European Urban Atlas; European Environment Agency, 2010) data extents. Known colloquially as 'The Potteries', the city of Stoke-on-Trent was formed from a federation of 6 towns and several villages in the early $20^{\text {th }}$ Century. The urban area today covers approximately $93 \mathrm{~km}^{2}$ and supports a population of 249,000 (Office for National Statistics, 2015). The city lies in the North Staffordshire Coalfield where coal, clay and ironstone mining plus brick, tile and pottery production were the mainstays of the area's economy during the $19^{\text {th }}$ and $20^{\text {th }}$ centuries. Current land use is typified by urban fabric of variable density within the city itself and 'agricultural' and 'semi-natural areas and wetlands' in the neighbouring rural areas (Figure 1). 


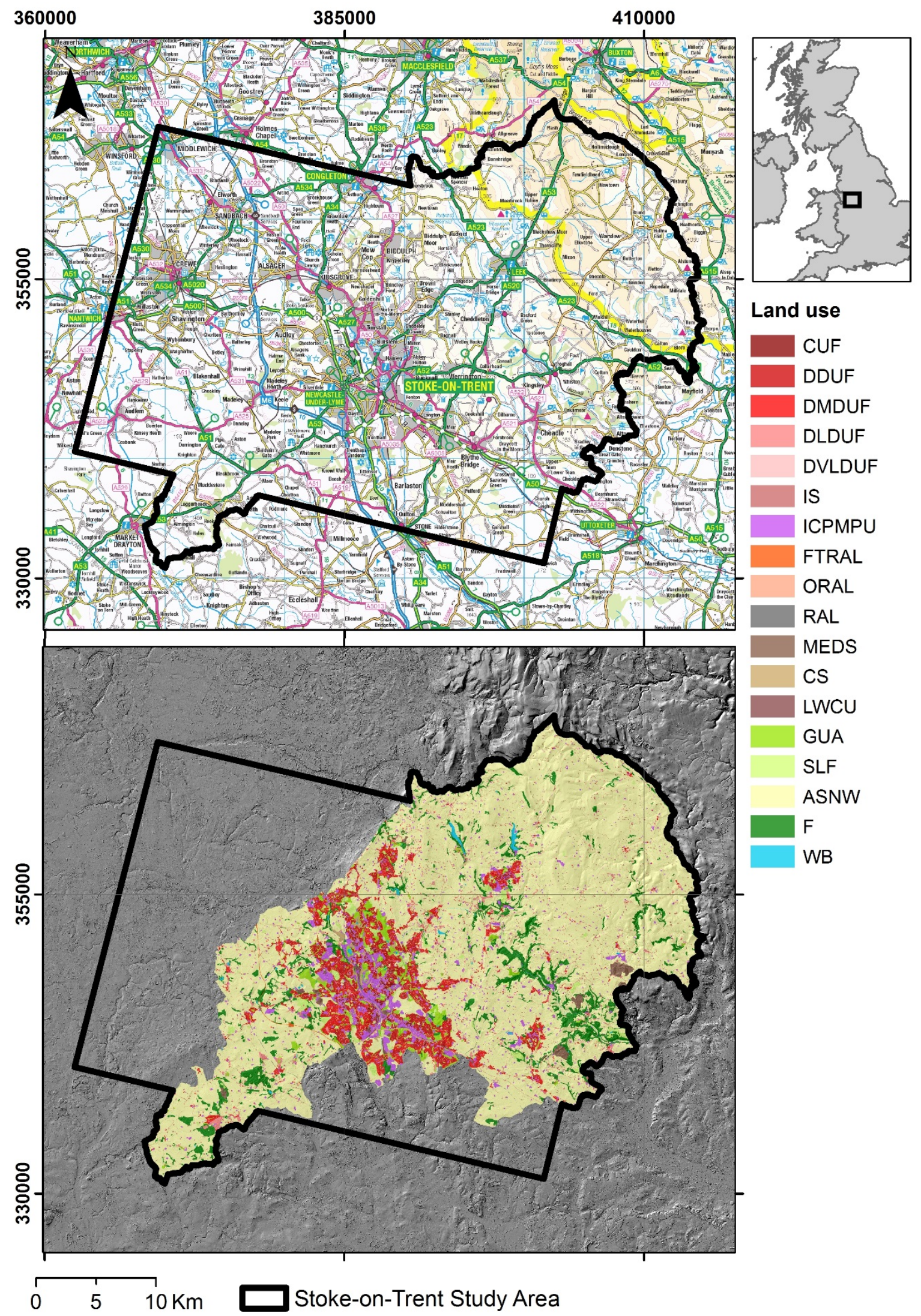

Figure 1. The Stoke-on-Trent, UK study area location (top) and land use (bottom). Inset: Rectangle denotes location of study area in the UK. Land use categories derived from the European Urban Atlas (European Environment Agency, 2010): CUF Continuous urban fabric; DDUF Discontinuous dense urban fabric; DMDUF Discontinuous medium density urban 
fabric; DLDUF Discontinuous low density urban fabric; DVLDUF Discontinuous very low density urban fabric; IS Isolated structures; ICPMPU Industrial, commercial, public, military and private units; FTRAL Fast transit roads and associated land; ORAL Other roads and associated land; RAL Railways and associated land; MEDS Mineral extraction and dump sites; CS Construction sites; LWCU Land without current use; GUA Green urban areas; SLF Sports and leisure facilities; ASNW Agricultural, semi-natural areas and wetlands; $F$ Forests and; WB Water bodies. Contains Ordnance Survey data (C) Crown Copyright and database rights 2017. Ordnance Survey Licence no. 100021290. GMES EEA Urban Atlas @ EEA 2013. NextMap ${ }^{\circledR}$ Britain elevation data (C) 2003, Intermap Technologies.

Geologically and topographically the area can be divided into two distinct regions (Figure 2). To the west and north-west and covering approximately a third of the study area is the Cheshire Basin. Characterised by subdued, gently undulating topography with lows of around 40 mOD (metres above Ordnance Datum) and isolated highs of around 150 mOD, this region comprises the Mercia Mudstone Group (Triassic Rocks (Undifferentiated) in Figure 2) with overlying Devensian Till and patches of glacial sand and gravel. A peak elevation of $343 \mathrm{mOD}$ is achieved along the eastern edge of the basin which is orientated north-east, south-west near the centre of the study area. The remainder of the region is characterised by higher elevations and steeper slopes with incised drainage channels. Elevations in this area rise from approximately $160 \mathrm{mOD}$ in the south to a maximum of 505 $\mathrm{mOD}$ in the north-east which lies in the Peak District National Park. The majority of this portion of the study area is underlain by Carboniferous rocks of the Millstone Grit and Warwickshire groups. Triassic and Permian rocks are present to a lesser degree in the southern portion of this area. The superficial deposits of the area comprise patches of Devensian Till and Alluvium. Within the study site as a whole, natural superficial deposits are overlain locally by Made and Infilled ground. These may include brick and tile waste, colliery waste and/ or domestic and industrial waste. 


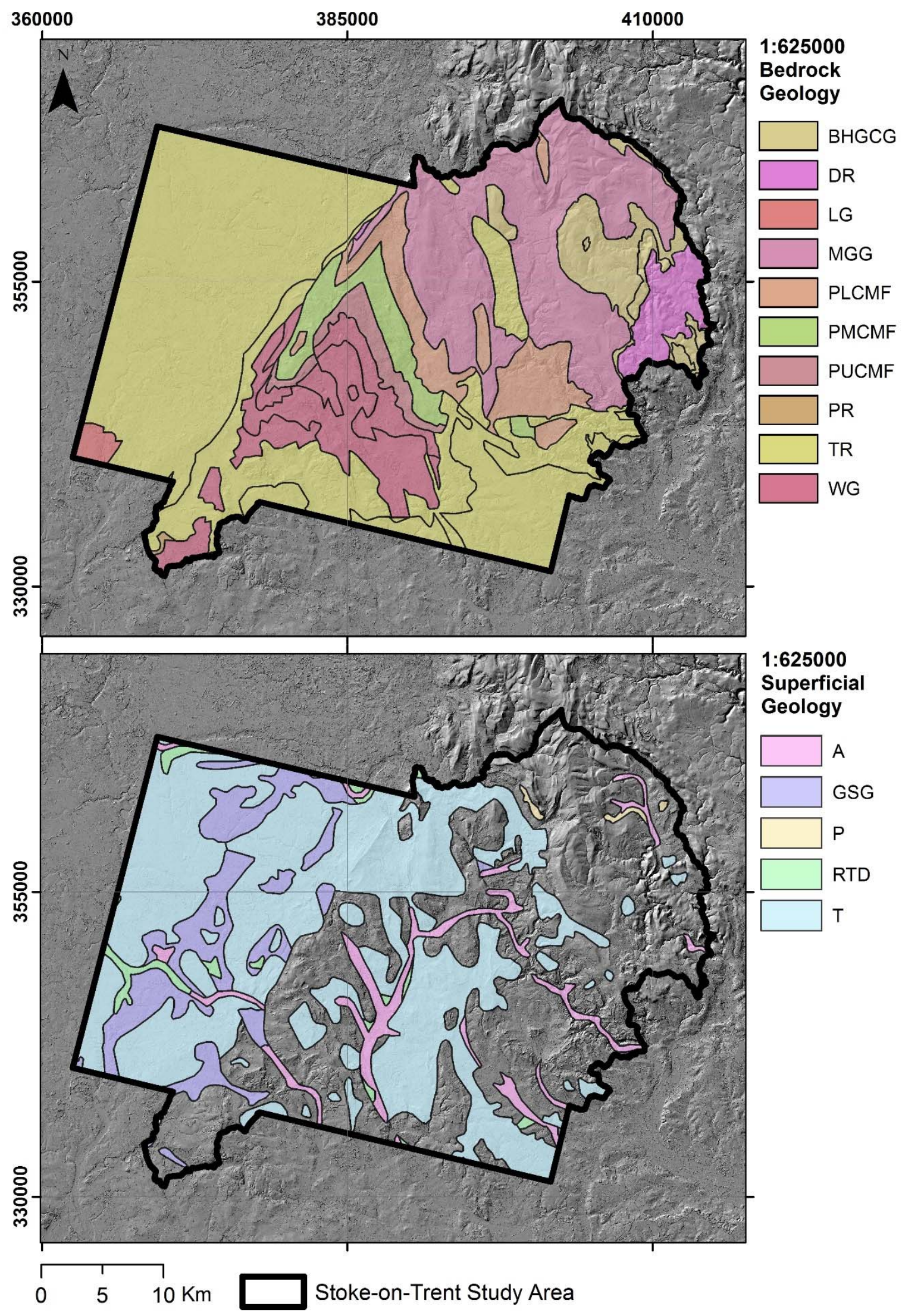

Figure 2. Topography and 1: 625000 scale bedrock (top) and superficial (bottom) geology of the Stoke-on-Trent study area. Bedrock geology codes: BHGCG Bowland High Group and Craven Group (Undifferentiated); DR Dinantian Rocks (Undifferentiated) ; LG Lias Group; MGG Millstone Grit Group; PLCMF Pennine Lower Coal Measures Formation and South 
Wales Lower Coal Measures Formation (Undifferentiated); PMCMF Pennine Middle Coal Measures Formation and South Wales Middle Coal Measures Formation (Undifferentiated); PUCMF Pennine Upper Coal Measures Formation; PR Permian Rocks (Undifferentiated); TR Triassic Rocks (Undifferentiated); WG Warwickshire Group. Superficial geology codes: $A$ Alluvium; GSG Glacial Sand and Gravel; P Peat; RTD River Terrace Deposits (Undifferentiated); $T$ Till. NextMap ${ }^{\circledR}$ Britain elevation data (C) 2003, Intermap Technologies.

\section{Methodology}

The methodology employed by the PanGeo project is described in detail in the PanGeo Production Manual (Bateson et al., 2012; http://www.pangeoproject.eu/eng/documents). The PanGeo project mapped areas of a given urban area affected by ground instability (past, present and potential future instabilities) using a variety of PSI and geospatial data integrated in a GIS environment. Interpretation was performed by geologists, geohazard specialists and earth observation professionals and areas of instability were defined as attributed vector polygons to form a 'Ground Stability Layer'. This is supported by detailed descriptions of the likely cause of motion (the 'Geohazard Description Document'). Portions of the methodology specific to the Stoke-on-Trent study site are outlined below.

The PSI motion dataset was derived by Tele-Rilevamento Europa through processing 70 ERS1/2 SAR descending mode scenes acquired between 1992 and 2003 following the standard approach to the Permanent Scatterers InSAR (PSInSAR ${ }^{\mathrm{TM}}$ ) technique (Ferretti et al., 2004). The processed dataset covers $1,026 \mathrm{~km}^{2}, 74 \%$ of the study area. Exceptions include a small region around Ashley Heath (National Grid Reference (NGR) 375475, 336475) in the southwest and a larger region in the vicinity of Warslow (NGR 408670, 358602) to the north-east.

PSInSAR ${ }^{\mathrm{TM}}$ processing of the ERS-1/2 data stack allowed the extraction of $178,109 \mathrm{PS}$, corresponding to a maximum density of $2018 \mathrm{PS} / \mathrm{km}^{2}$, minimum density of $0 \mathrm{PS} / \mathrm{km}^{2}$, average density of $118 \mathrm{PS} / \mathrm{km}^{2}$ and standard deviation of $255 \mathrm{PS} / \mathrm{km}^{2}$ across the study area. For each of these points, a linear motion rate and standard deviation; detailed motion time series and; precise height correction were calculated. An overview of the distribution of the identified PS and their average motion velocities is shown in Figure 3. PS densities are greatest over urban fabric in the centre of the area with lower densities displayed in rural and more heavily vegetated regions (Figure 4). 


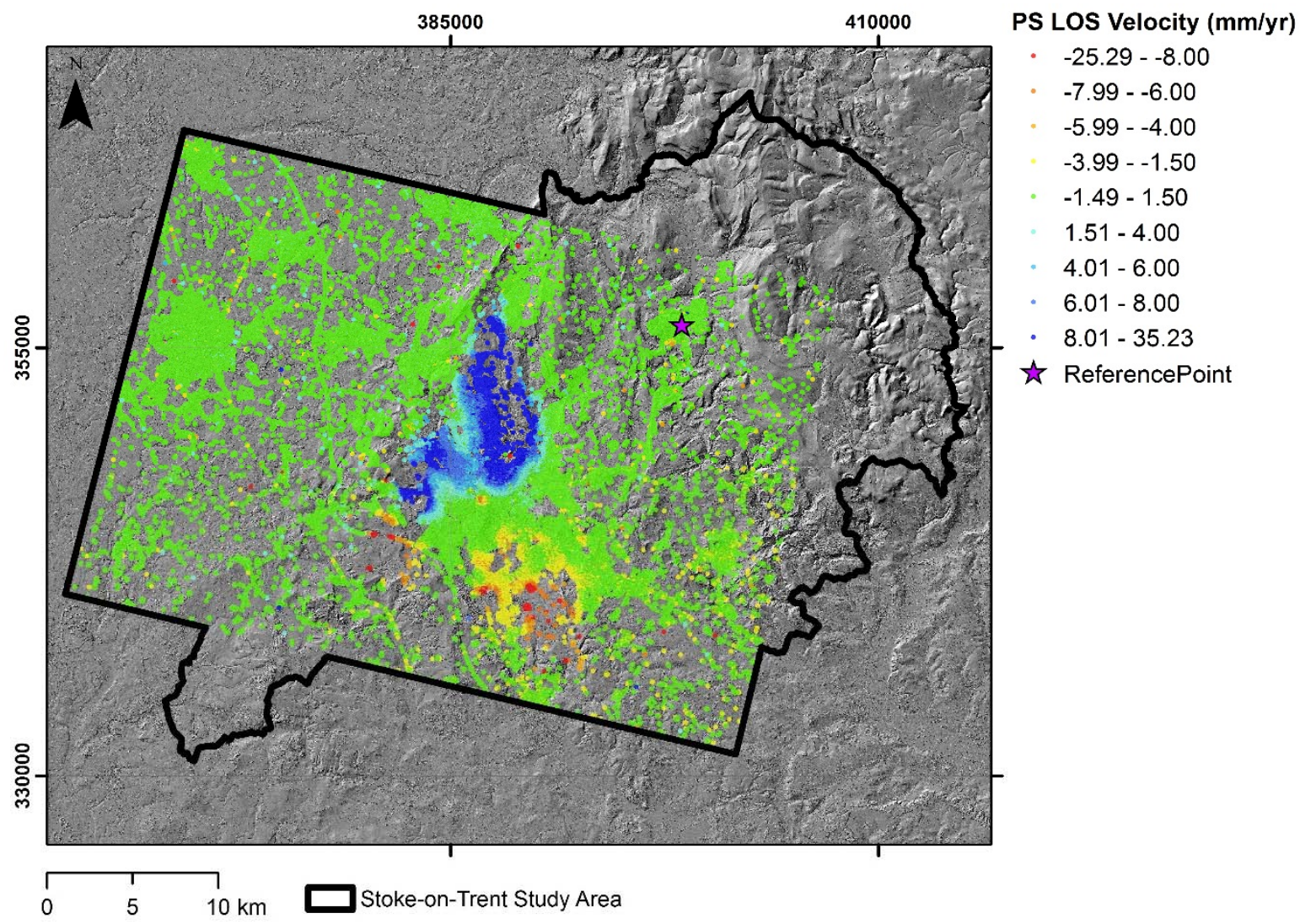

Figure 3. Average Persistent Scatterer (PS) Line of Sight (LOS) motion velocities in the Stokeon-Trent study area. Green PS are considered stable with respect to the reference point location (Leek: NGR 398506, 356343). Yellow to red PS indicate motion away from the sensor and light to dark blue PS indicate motion towards the sensor. NextMap ${ }^{\circledR}$ Britain elevation data (C) 2003, Intermap Technologies. 


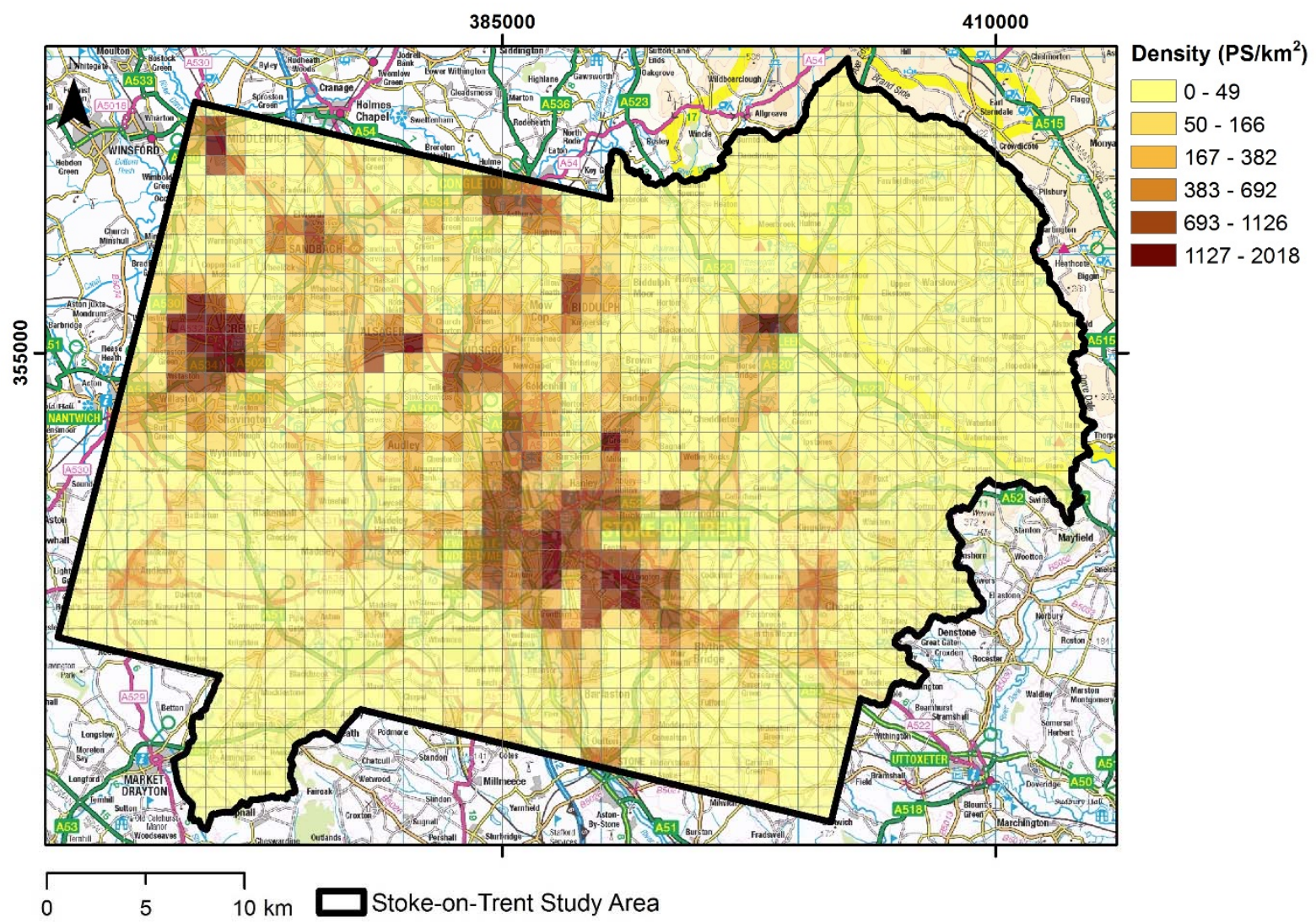

Figure 4. PS density across the Stoke-on-Trent study area. The highest densities correspond with urban centres. Densities were calculated using a $1 \mathrm{~km}$ grid and natural jenks classification. Contains Ordnance Survey data (C) Crown Copyright and database rights 2017. Ordnance Survey Licence no. 100021290.

The ERS- $1 / 2$ satellites' inclination of the ground track is approximately $13^{\circ}$ with respect to the S-N axis at Stoke-on-Trent's latitude and the look angle of the employed sensor mode approaches $23^{\circ}$ (from vertical). As such, purely vertical motions were estimated at $\sim 92 \%$ of their actual amount, E-W motions at $\sim 38 \%$, and N-S at $\sim 9 \%$. The repeat cycle of the satellites varied throughout the study period, with sampling cycles of 3 days, 35 days and 168 days. Of the 70 scenes used in this project, $63 \%$ are separated by 35 days +/- 1 day and $13 \%$ have a spacing of 1 day (a result of the tandem orbit of the satellites). The remainder have intervals reflecting multiples of the 35 and 3 day sampling cycles. Geocoding accuracy of the PSI data is $\pm 5 \mathrm{~m}$ in the E-W direction and $\pm 10 \mathrm{~m}$ in the N-S direction. The dataset reference point was located in the town of Leek (NGR 398506, 356343). This was selected on the basis of interferometric stability of the PS candidates and a stable geological setting (relative to alternative parts of the study area).

Average annual motion velocities along the ERS-1/2 Line of Sight (LOS) range between -25.29 and $+35.23 \mathrm{~mm} / \mathrm{yr}$ with an average across the entire processing area of $+0.73 \mathrm{~mm} / \mathrm{yr}$ and standard deviation of $\pm 2.57 \mathrm{~mm} / \mathrm{yr}$. As a result, PS showing annual deformation velocities in the range of $\pm 1.50 \mathrm{~mm} / \mathrm{yr}$ along the LOS are considered as stable and colour-coded green (Figure 3). Yellow to red PS indicate motions recorded away from the sensor (negative LOS velocities) while light to dark blue indicate motions towards the sensor (positive LOS velocities). 
Ground motion estimates derived from PSI were supported by a range of geospatial data, as summarised in Table 1. Interpretations of ground motion detected in the area from PSI as part of the European Space Agency Terrafirma project (Culshaw et al., 2006) were examined in the current research and where relevant incorporated into the Ground Stability Layer. The aim of the Terrafirma project was to assess the general validity of the early PSI processing techniques and to begin identifying potential geological explanations for the motions revealed.

\begin{tabular}{|c|c|c|c|c|}
\hline Group & Data & Type & $\begin{array}{l}\text { Scale/ } \\
\text { resolution }\end{array}$ & Availability \\
\hline \multirow{4}{*}{$\begin{array}{l}\text { वेo } \\
\frac{0}{0} \\
\stackrel{d}{0}\end{array}$} & DiGMapGB-625K; -50K & $\begin{array}{l}\text { Superficial deposits; } \\
\text { Bedrock deposits; } \\
\text { Faults, Folds, Landforms; } \\
\text { Artificial ground }\end{array}$ & $\begin{array}{l}\text { 1: } 625000 \\
\text { 1: } 50000\end{array}$ & (C) NERC (Free) \\
\hline & DiGMapGB--10K; -PLUS & $\begin{array}{l}\text { As above plus Engineering geology } \\
\text { properties }\end{array}$ & $\begin{array}{l}\text { 1: } 10000 ; 1: \\
50000\end{array}$ & $\begin{array}{l}\text { (c) NERC } \\
\text { (Commercial) }\end{array}$ \\
\hline & $\begin{array}{l}\text { Superficial Deposits } \\
\text { Thickness Model (SDTM) }\end{array}$ & Deposit thickness & $\begin{array}{l}50 \mathrm{~m} \text { grid, } \\
\text { based on } \\
1: 50000 \\
\text { data }\end{array}$ & $\begin{array}{l}\text { (C) NERC } \\
\text { (Commercial) }\end{array}$ \\
\hline & $\begin{array}{l}\text { Single Onshore Boreholes } \\
\text { Index (SOBI) }\end{array}$ & Borehole locations \& scanned logs & N/A & $\begin{array}{l}\text { (C) NERC (Free via } \\
\text { Geolndex WMS } \\
\text { and GeoRecords } \\
\text { Plus+) }\end{array}$ \\
\hline \multirow{3}{*}{ 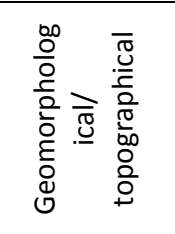 } & OS Base Maps, & Topographic map & $\begin{array}{l}\text { 1: } 50000 ; 1: \\
10000\end{array}$ & $\begin{array}{l}\text { (C) Crown } \\
\text { Copyright } \\
\text { reserved }\end{array}$ \\
\hline & NextMap & Digital Surface Model & $5 \mathrm{~m}$ & $\begin{array}{l}\text { (C) Intermap } \\
\text { Technologies }\end{array}$ \\
\hline & Aerial photographs & Aerial photographs & $0.25 \mathrm{~m}$ & (C) UK Perspectives \\
\hline \multirow{2}{*}{ 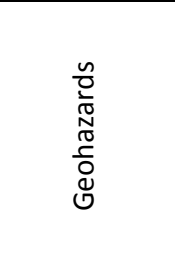 } & $\begin{array}{l}\text { Landslides- DiGMap50k } \\
\text { mass; National Landslide } \\
\text { Database }\end{array}$ & $\begin{array}{l}\text { Mass movements; Landslide locations } \\
\text { and proforma }\end{array}$ & $\begin{array}{l}1 ; 50000 ; \\
\text { N/A }\end{array}$ & $\begin{array}{l}\text { (C) NERC (Free via } \\
\text { Geolndex) }\end{array}$ \\
\hline & $\begin{array}{l}\text { Cavities- National Karst } \\
\text { Database; Caves Mines; } \\
\text { Address-Linked Geological } \\
\text { Inventory (ALGI) }\end{array}$ & $\begin{array}{l}\text { Geomorphology, damage; Caves, } \\
\text { mines, collapses; Chalk workings \& } \\
\text { Natural hazards }\end{array}$ & N/A & (C) NERC \\
\hline Land use & EEA GMES Urban Atlas & Land Cover types & $1: 10000$ & $\begin{array}{l}\text { (C) DG Enterprise } \\
\text { and Industry }\end{array}$ \\
\hline Hydrological & $\begin{array}{l}\text { WellMaster } \\
\text { hydrogeological database }\end{array}$ & Water well archive & $\mathrm{N} / \mathrm{A}$ & $\begin{array}{l}\text { (C) NERC (Free via } \\
\text { Geolndex) }\end{array}$ \\
\hline
\end{tabular}

Table 1. Satellite and geospatial data used in the identification of geohazards in the Stokeon-Trent area.

\section{Results and discussion}

\subsection{Geohazards in the Stoke-on-Trent study area}

A total of 14 geohazard polygons have been identified (Table 2; Figure 5- note that areas of ground motion attributed to landsliding have been mapped as 1 multi-part polygon): 13 of these correspond to ground motion observed from the combination of PSI and geospatial data and 1 from geospatial data alone. The polygons cover a total of $122.35 \mathrm{~km}^{2}$ and areas of uplift, subsidence and down-slope movement are observed. A range of geohazard types have been identified including anthropogenically-induced instability caused by mining and made ground as well as natural ground instability resulting from landsliding and the dissolution of halites. There are three small polygons where the cause of movement is 
unknown. The geohazards are defined as single-part polygons, with the exception of the 167 landslides identified which, in accordance with the PanGeo project methodology, were grouped into 1 multi-part polygon. Comparison of these results with the 51 other PanGeo cities, ranks Stoke-on-Trent $28^{\text {th }}$ for percentage of the city affected by geohazards, $19^{\text {th }}$ for number of geohazard types present and $23^{\text {rd }}$ for population exposed to geohazards (Capes \& Teeuw, 2017). 


\begin{tabular}{|c|c|c|c|c|c|c|c|c|c|c|c|c|c|c|}
\hline \multirow{3}{*}{ Polygon ID } & \multirow{2}{*}{\multicolumn{2}{|c|}{ Hazard }} & \multirow{3}{*}{$\begin{array}{l}\text { Motion } \\
\text { type }\end{array}$} & \multirow{3}{*}{$\begin{array}{l}\text { Determination } \\
\text { method }\end{array}$} & \multirow{3}{*}{$\begin{array}{l}\text { Confidence } \\
\text { level }\end{array}$} & \multirow{3}{*}{$\begin{array}{c}\text { Polygon } \\
\text { area } \\
\left(\mathrm{km}^{2}\right)\end{array}$} & \multirow{2}{*}{\multicolumn{2}{|c|}{ Observation date }} & \multicolumn{6}{|c|}{ ERS-1/2 data 1992-2003 } \\
\hline & & & & & & & & & \multirow{2}{*}{$\begin{array}{l}\text { PS } \\
\text { count }\end{array}$} & \multirow{2}{*}{$\begin{array}{c}\text { PS density } \\
\text { (points/k } \\
\mathrm{m}^{2} \text { ) }\end{array}$} & \multicolumn{4}{|c|}{ LOS Velocity (mm/yr) } \\
\hline & Category & Type & & & & & Start & End & & & Avg. & Min. & Max. & SD \\
\hline 01 & $\begin{array}{l}\text { Anthropogenically-induced } \\
\text { ground instability }\end{array}$ & Mining & Uplift & Observed PSI & Medium & 59.64 & $11 / 05 / 1992$ & $27 / 02 / 2003$ & 20,360 & 341.38 & 6.28 & -20.39 & 35.23 & 3.45 \\
\hline 02 & Unknown & Unknown & Subsidence & Observed PSI & Medium & 0.393 & $11 / 05 / 1992$ & $27 / 02 / 2003$ & 182 & 463.15 & -2.69 & -7.11 & -0.35 & 1.21 \\
\hline 03 & $\begin{array}{l}\text { Anthropogenically-induced } \\
\text { ground instability }\end{array}$ & Mining & Subsidence & Observed PSI & Medium & 40.00 & $11 / 05 / 1992$ & $27 / 02 / 2003$ & 11,127 & 278.19 & -2.34 & -18.26 & 1.55 & 1.66 \\
\hline 04 & Unknown & Unknown & Subsidence & Observed PSI & Medium & 0.328 & $11 / 05 / 1992$ & $27 / 02 / 2003$ & 389 & 1184.54 & -1.89 & -5.23 & 0.40 & 0.92 \\
\hline 05 & $\begin{array}{l}\text { Anthropogenically-induced } \\
\text { ground instability }\end{array}$ & $\begin{array}{l}\text { Artificial } \\
\text { ground }\end{array}$ & Subsidence & Observed PSI & Low & 0.071 & $11 / 05 / 1992$ & $27 / 02 / 2003$ & 91 & 1287.48 & -2.14 & -4.91 & 0.15 & 1.08 \\
\hline 06 & $\begin{array}{l}\text { Anthropogenically-induced } \\
\text { ground instability }\end{array}$ & Mining & Subsidence & Observed PSI & Medium & 14.383 & $11 / 05 / 1992$ & $27 / 02 / 2003$ & 578 & 40.19 & -3.66 & -22.57 & 0.32 & 3.52 \\
\hline 07 & $\begin{array}{l}\text { Anthropogenically-induced } \\
\text { ground instability }\end{array}$ & $\begin{array}{l}\text { Artificial } \\
\text { ground }\end{array}$ & $\begin{array}{c}\text { Uplift \& } \\
\text { subsidence }\end{array}$ & Observed PSI & Medium & 0.223 & $11 / 05 / 1992$ & $27 / 02 / 2003$ & 271 & 1215.19 & 0.48 & -5.22 & 3.77 & 1.99 \\
\hline 08 & $\begin{array}{c}\text { Natural } \\
\text { Ground Instability } \\
\end{array}$ & $\begin{array}{c}\text { Ground } \\
\text { dissolution }\end{array}$ & Subsidence & Observed PSI & Medium & 0.032 & $11 / 05 / 1992$ & $27 / 02 / 2003$ & 11 & 1199.12 & -1.72 & -2.68 & 0.29 & 0.97 \\
\hline 09 & $\begin{array}{l}\text { Anthropogenically-induced } \\
\text { ground instability }\end{array}$ & $\begin{array}{l}\text { Artificial } \\
\text { ground }\end{array}$ & Subsidence & Observed PSI & Low & 0.004 & $11 / 05 / 1992$ & $27 / 02 / 2003$ & 17 & 3007.41 & -1.69 & -3.33 & -0.55 & 0.80 \\
\hline 10 & $\begin{array}{l}\text { Anthropogenically-induced } \\
\text { ground instability }\end{array}$ & $\begin{array}{l}\text { Artificial } \\
\text { ground }\end{array}$ & Subsidence & Observed PSI & Medium & 0.045 & $11 / 05 / 1992$ & $27 / 02 / 2003$ & 49 & 378.11 & -2.08 & -4.47 & -0.84 & 0.79 \\
\hline 11 & Unknown & Unknown & Subsidence & Observed PSI & Low & 0.014 & $11 / 05 / 1992$ & $27 / 02 / 2003$ & 30 & 3586.56 & -3.13 & -10.05 & -0.96 & 2.03 \\
\hline 12 & $\begin{array}{c}\text { Natural } \\
\text { Ground Instability }\end{array}$ & $\begin{array}{l}\text { Ground } \\
\text { dissolution }\end{array}$ & Subsidence & Observed PSI & Medium & 0.072 & $11 / 05 / 1992$ & $27 / 02 / 2003$ & 30 & 422.85 & -1.75 & -6.56 & 1.30 & 2.59 \\
\hline 13 & $\begin{array}{l}\text { Anthropogenically-induced } \\
\text { ground instability }\end{array}$ & $\begin{array}{l}\text { Made } \\
\text { ground }\end{array}$ & Subsidence & Observed PSI & Low & 0.041 & $11 / 05 / 1992$ & $27 / 02 / 2003$ & 26 & 782.54 & -1.45 & -3.67 & 1.58 & 1.14 \\
\hline 14 & $\begin{array}{c}\text { Natural } \\
\text { Ground Instability }\end{array}$ & Landslide & $\begin{array}{l}\text { Down } \\
\text { slope }\end{array}$ & $\begin{array}{c}\text { Observed } \\
\text { Geology } \\
\text { Field Campaigns }\end{array}$ & External & 7.106 & $14 / 10 / 2010$ & $14 / 10 / 2010$ & 38 & 3.66 & -0.04 & -3.93 & 4.12 & 1.99 \\
\hline
\end{tabular}


Table 2. Observed geohazards and associated PSI statistics in the Stoke-on-Trent area. Note observation dates are defined by the data source and do not necessarily refer to the actual dates of motion.

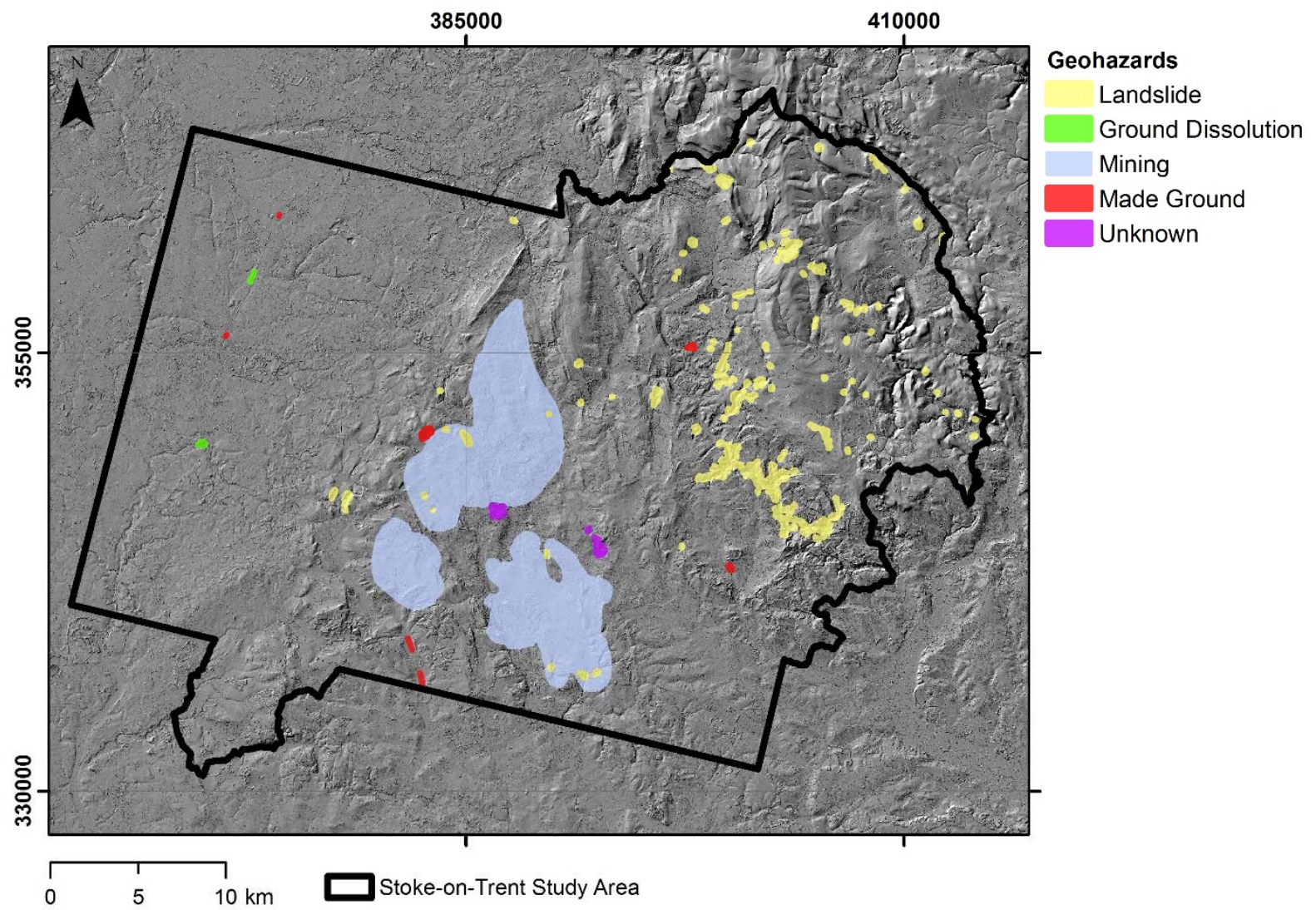

Figure 5. Geohazard location and type in the Stoke-on-Trent study area identified from PSI and geospatial data. The ground motion has been attributed to a range of natural and anthropogenic processes. NextMap ${ }^{\circledR}$ Britain elevation data (C) 2003, Intermap Technologies.

The dominant geohazard (in terms of area covered) is ground movement caused by postmining groundwater recharge and mining-related subsidence $(93.2 \%$ of total geohazard area). This is followed by landsliding (5.8\%), cause of movement unknown (0.6\%), made ground $(0.3 \%)$ and ground dissolution $(0.1 \%)$. In a few areas geohazards of different types overlap ( $0.2 \%$ of the total geohazard polygon area). For example, landslides have occurred in areas affected by post-mining groundwater recharge and mining-related subsidence. 9 medium, 4 low and 1 external (derived solely from a geospatial data source rather than from the PSI data) confidence level polygons have been identified.

Ground motion statistics for the PSI data reveal the maximum, minimum and average velocity of all the PS points identified within the polygons (Table 2). Note that not all of the multi-part landslide polygon (polygon 14) is covered by the PSI dataset (an artefact of the different spatial extents of the PSI data and the study area). LOS velocities as high as +35.00 $\mathrm{mm} / \mathrm{yr}$ are found in polygon 01, whilst peak motions away from the satellite are observed in polygon $06(-22.57 \mathrm{~mm} / \mathrm{yr})$. Heterogeneity in LOS velocity is observed within the polygons, as indicated by standard deviation: polygons 01,06 and 12 are especially heterogeneous. Potential causes of LOS heterogeneity include the operation of different rates of motion across the polygon area caused by the same process (for example, peak ground motion is 
observed in the centre of polygon 01 and this decreases outwards); changes in the rate/ direction of ground motion through time (for example, mine closures and resultant groundwater recharge affecting polygon 01 occurred at different times) and; the operation of different processes across the area (for example, the use of a number of different mining techniques may have contributed to instability in polygon 06 and artificial brine pumping is likely to have compounded natural dissolution in polygon 12). Different PS point densities can also be seen across the polygons, ranging from a maximum of 3586.56 points $/ \mathrm{km}^{2}$ to as little as 3.66 points $/ \mathrm{km}^{2}$.

The landuse most affected by geohazards within the Stoke-on-Trent study area is 'Construction sites' (European Urban Atlas land use type; see Figure 1 for categories), with $65.02 \%$ of these areas displaying ground instability. This is followed by 'Continuous urban fabric' (55.17\%), 'Land without current use' (53.53\%) and 'Green urban areas' (52.48 \%). The least affected land use is 'Discontinuous very low density urban fabric' $(0.38 \%$; note that no PS are evident in this land use). These figures include areas where the geohazard polygons overlap (i.e. an area affected by two different geohazards will have been included twice in the above calculations). As the total area of overlap is very small ( $<2 \%$ of the geohazard area) this is unlikely to significantly affect the overall calculations.

The results of examining PSI data characteristics by land use type are demonstrated in Table 3. Note that as the Urban Atlas and PSI data differ in their spatial extent, only areas with coverage of both datasets are included here; a total area of $601.86 \mathrm{~km}^{2}$. This excludes 31.62 $\%$ of the European Urban Atlas area, $45.71 \%$ of the PSI area and $18.07 \%$ of the geohazard polygon area and accounts for the slight difference in area values reported in Table 3 and above. 'Discontinuous medium density urban fabric' records the highest maximum LOS velocity $(35.23 \mathrm{~mm} / \mathrm{yr}$ ) and 'Fast transit roads and associated land' the greatest minimum velocity $(-22.57 \mathrm{~mm} / \mathrm{yr})$. 'Continuous urban fabric' shows the highest average velocity towards the satellite $(5.08 \mathrm{~mm} / \mathrm{yr})$, the highest PS density (1262.92 points $\left./ \mathrm{km}^{2}\right)$ and one of the lower standard deviations $(4.15 \mathrm{~mm} / \mathrm{yr})$. 'Fast transit roads and associated land' displays the highest average velocity away from the satellite $(-5.45 \mathrm{~mm} / \mathrm{yr})$ and the greatest minimum velocity $(-22.57 \mathrm{~mm} / \mathrm{yr})$ but one of the highest standard deviations $(6.14 \mathrm{~mm} / \mathrm{yr})$. Both subsidence and uplift are observed for all land use types with the exception of 'Isolated structures' which record only movement away from the satellite. 


\begin{tabular}{|c|c|c|c|c|c|c|c|c|c|}
\hline \multirow{3}{*}{ Land cover type (Urban Atlas (UA) category) } & \multicolumn{2}{|c|}{ Area $\left[\mathrm{km}^{2}\right]$} & \multirow{3}{*}{$\begin{array}{l}B / A \\
{[\%]}\end{array}$} & \multicolumn{6}{|c|}{ ERS-1/2 PSInSAR ${ }^{T M}$ data in 1992-2003 } \\
\hline & \multirow{2}{*}{$\begin{array}{l}\text { Stoke-on- } \\
\text { Trent UA } \\
\text { (A) }\end{array}$} & \multirow{2}{*}{$\begin{array}{c}\text { Observed } \\
\text { geohazards } \\
\text { within UA (B) }\end{array}$} & & \multirow{2}{*}{ PS count } & \multirow{2}{*}{$\begin{array}{c}\text { PS density } \\
\text { (points/ km²) }\end{array}$} & \multicolumn{4}{|c|}{ LOS velocity (VEL) [mm/yr] } \\
\hline & & & & & & Avg. & Min. & Max. & SD \\
\hline Continuous urban fabric & 2.136 & 1.178 & 55.2 & 1,488 & 1262.92 & 5.08 & -3.58 & 33.46 & 4.15 \\
\hline Discontinuous dense urban fabric & 31.808 & 15.529 & 48.8 & 12,295 & 791.75 & 3.21 & -10.73 & 35.01 & 4.86 \\
\hline Discontinuous medium density urban fabric & 28.938 & 7.103 & 24.5 & 5,354 & 753.75 & 2.34 & -13.91 & 35.23 & 5.16 \\
\hline Discontinuous low density urban fabric & 9.758 & 0.722 & 7.4 & 309 & 427.93 & -0.40 & -17.86 & 18.09 & 4.58 \\
\hline Discontinuous very low density urban fabric & 0.657 & 0.002 & 0.4 & 0 & 0.00 & - & - & - & - \\
\hline Isolated structures & 3.576 & 0.153 & 4.3 & 30 & 196.24 & -3.56 & -6.89 & -0.70 & 1.56 \\
\hline Industrial, commercial, public, military and private units & 33.870 & 13.585 & 40.1 & 8,481 & 624.28 & 3.21 & -14.10 & 31.43 & 5.08 \\
\hline Fast transit roads and associated land & 0.643 & 0.226 & 35.2 & 113 & 498.90 & -5.45 & -22.57 & 1.77 & 6.14 \\
\hline Other roads and associated land & 19.457 & 5.856 & 30.1 & 1,952 & 333.35 & 4.03 & -14.54 & 26.39 & 4.81 \\
\hline Railways and associated land & 0.947 & 0.232 & 24.5 & 93 & 400.13 & 0.21 & -6.34 & 7.16 & 3.27 \\
\hline Mineral extraction and dump sites & 2.831 & 0.489 & 17.3 & 4 & 8.18 & -0.42 & -1.82 & 0.34 & 0.96 \\
\hline Construction sites & 2.796 & 1.846 & 66.0 & 766 & 414.94 & 4.94 & -10.05 & 19.21 & 3.40 \\
\hline Land without current use & 1.895 & 1.014 & 53.5 & 387 & 381.59 & 3.69 & -6.33 & 11.82 & 2.53 \\
\hline Green urban areas & 20.958 & 11.213 & 53.5 & 249 & 22.21 & 3.12 & -8.44 & 23.01 & 4.86 \\
\hline Sports and leisure facilities & 13.795 & 5.227 & 37.9 & 491 & 93.94 & 4.39 & -5.95 & 26.84 & 5.38 \\
\hline Agricultural, semi-natural areas and wetlands & 382.508 & 27.454 & 7.2 & 143 & 5.21 & 2.12 & -16.77 & 25.71 & 7.72 \\
\hline Forests & 42.443 & 5.539 & 13.1 & 19 & 3.43 & 0.07 & -4.74 & 10.34 & 4.42 \\
\hline Water bodies & 2.848 & 0.511 & 17.9 & 36 & 70.47 & 3.15 & -20.39 & 7.41 & 4.37 \\
\hline
\end{tabular}

Table 3. PSI statistics for individual land uses in the Stoke-on-Trent study area. 
The highest standard deviation of all land use types is recorded by 'Agricultural, seminatural and wetland areas' (7.72 mm/yr). Other rural areas, such as 'Water bodies' and 'Forests' record lower standard deviations ( $4.37 \mathrm{~mm} / \mathrm{yr}$ and $4.42 \mathrm{~mm} / \mathrm{yr}$ ) but possess very few PS. The more rural land uses also account for the lowest PS densities; 'Forests', 3.43 points $/ \mathrm{km}^{2}$; 'Agricultural, semi-natural and wetland areas', 5.21 and; 'Green urban areas', 22.21 points $/ \mathrm{km}^{2}$. This may be explained by the tendency of these land use types to be affected by temporal decorrelation and strong variations of interferometric phase, preventing the identification of good radar reflectors within the imagery stacks (e.g. Cigna et al., 2013a, b). The Intermittent Small Baseline Subset (ISBAS) method, developed recently and undergoing testing at BGS, is demonstrating encouraging results in reducing the effect of land use on PS density (Sowter et al., 2013; Bateson et al., 2015).

\subsection{Geohazard case studies}

This section examines selected detailed case studies for each of the four main types of geohazard present in the area. An overview of the geohazard polygons identified is presented in Jordan et al., (2013).

Three areas of mining-related ground instability have been identified in the region (Figure 5). The largest of these, polygon 01, is located in the centre of the study area and includes the urban areas of Goldenhill (NGR 386829, 353048), Tunstall (NGR 386908, 350508) and Hanley (NGR 388635, 348305) (Figure 6). Polygon 01 corresponds with the now disused collieries of the North Staffordshire Coalfield and bedrock geology (1: 625000 scale) is characterised by the Pennine Upper Coal Measures Formation, Pennine Middle Coal Measures Formation and South Wales Middle Coal Measures Formation (Undifferentiated), Pennine Lower Coal Measures Formation and South Wales Lower Coal Measures Formation (Undifferentiated) and, the Warwickshire Group.

Groundwater pumping was essential during coal mining and BGS Wellmaster data records water pumping rates of $\sim 3-6 \mathrm{l} / \mathrm{s}$ between 1950 and 1989 in the centre of the polygon and $10-15 \mathrm{l} / \mathrm{s}$ in its south-western portion between 1950 and 1969. The majority of the collieries in the area closed between the 1970s and 1990s and the cessation of groundwater pumping that followed is likely to have caused groundwater recharge and elastic rebound, shown in the PS data as motion towards the satellite. It is also apparent that this ground motion is accommodated by faults to the north and east of the polygon area (Culshaw et al., 2006). 


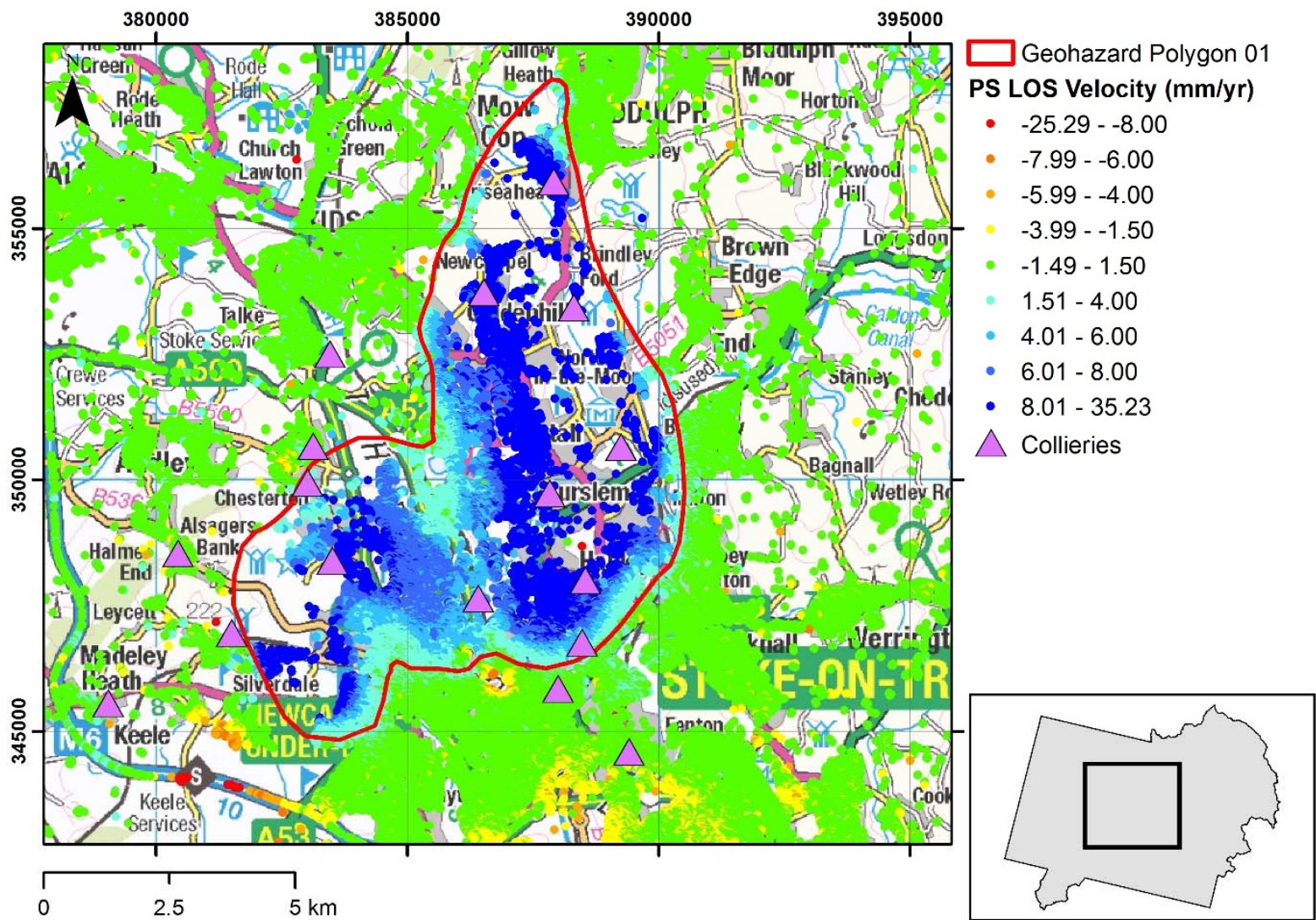

Figure 6. Average Persistent Scatterer (PS) Line of Sight (LOS) motion velocities for miningrelated instability (Geohazard Polygon 01 ) in the Stoke-on-Trent study area. The area of instability includes a number of collieries (locations after Rees \& Wilson, 1998). Contains Ordnance Survey data (C) Crown Copyright and database rights 2017. Ordnance Survey Licence no. 100021290.

Artificial ground-related instability accounts for five of the geohazard polygons in the Stokeon-Trent area (Figure 5). Located near Chesterton (NGR 382782, 350451) in the centre of the study area, polygon 07 indicates instability caused by a landfill site. Artificial deposits are mapped, in the form of infilled ground, with thicknesses ranging between 1-3 $\mathrm{m}$. Interestingly, the PS display different velocity trends across the polygon (Figure 7) with a region of uplift evident to the north-east and subsidence to the south-west. This is attributed to instability associated with backfilling of the former Glasshouse opencast coal pit which was located in the area (Rees \& Wilson, 1998). Such infilled ground is often subject to ground motion as waste materials settle causing subsidence and/or decay causing gas production and temporary uplift. Backfilling is believed to have taken place in the region of polygon 07 in two phases, resulting in the differential motion observed in the PS data (Culshaw et al., 2006). 


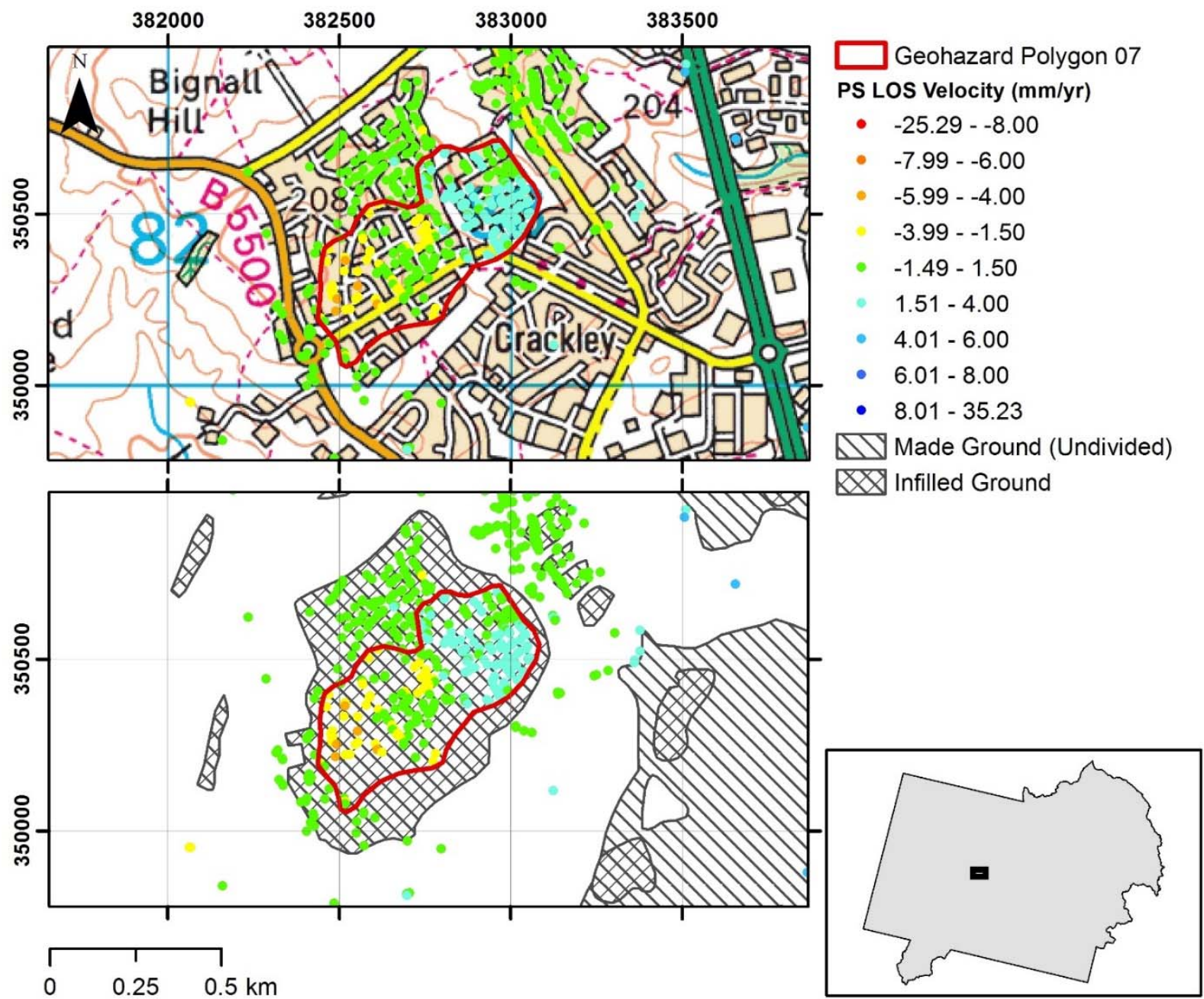

Figure 7. Average Persistent Scatterer (PS) Line of Sight (LOS) motion velocities for artificial ground-related instability (Geohazard Polygon 07) in the Stoke-on-Trent study area. Note that two distinct ground motion trends are visible within the polygon. The location of the geohazard polygon accords well with mapped extents of artificial deposits. Contains Ordnance Survey data (C) Crown Copyright and database rights 2017. Ordnance Survey Licence no. 100021290.

Two areas of ground motion attributed to dissolution are evident in Stoke-on-Trent (Figure 4). Polygon 08, is centred upon the railway line to the south of Sandbach (NGR 372777, 359301 ) in the north west of the study area. The region is low lying (elevations of $\sim 40 \mathrm{mOD}$ ) and characterised by wetlands of the Elton Flashes Nature Reserve (Figure 8). Alluvium, glaciofluvial deposits and Devensian Till, with thicknesses of 10-50 m, overlie the Wilkesley Halite Formation (Triassic Rocks (Undifferentiated) in Figure 2). The railway itself sits on an embankment of made ground. Motions away from the satellite sensor are observed (Table 2; Figure 8). The polygon lies within the Cheshire Salt Field, an area of readily soluble halite at rockhead (Rees \& Wilson, 1998). The BGS Karst Database documents subsidence hollows (dolines) in the area (Cooper, Farrant \& Price, 2011) and successive increases in these features through time and resulting distortion of the railway line are attributed to brine pumping (Cooper, 2002; Cooper, Farrant \& Price, 2011; Worsley, 2008). 


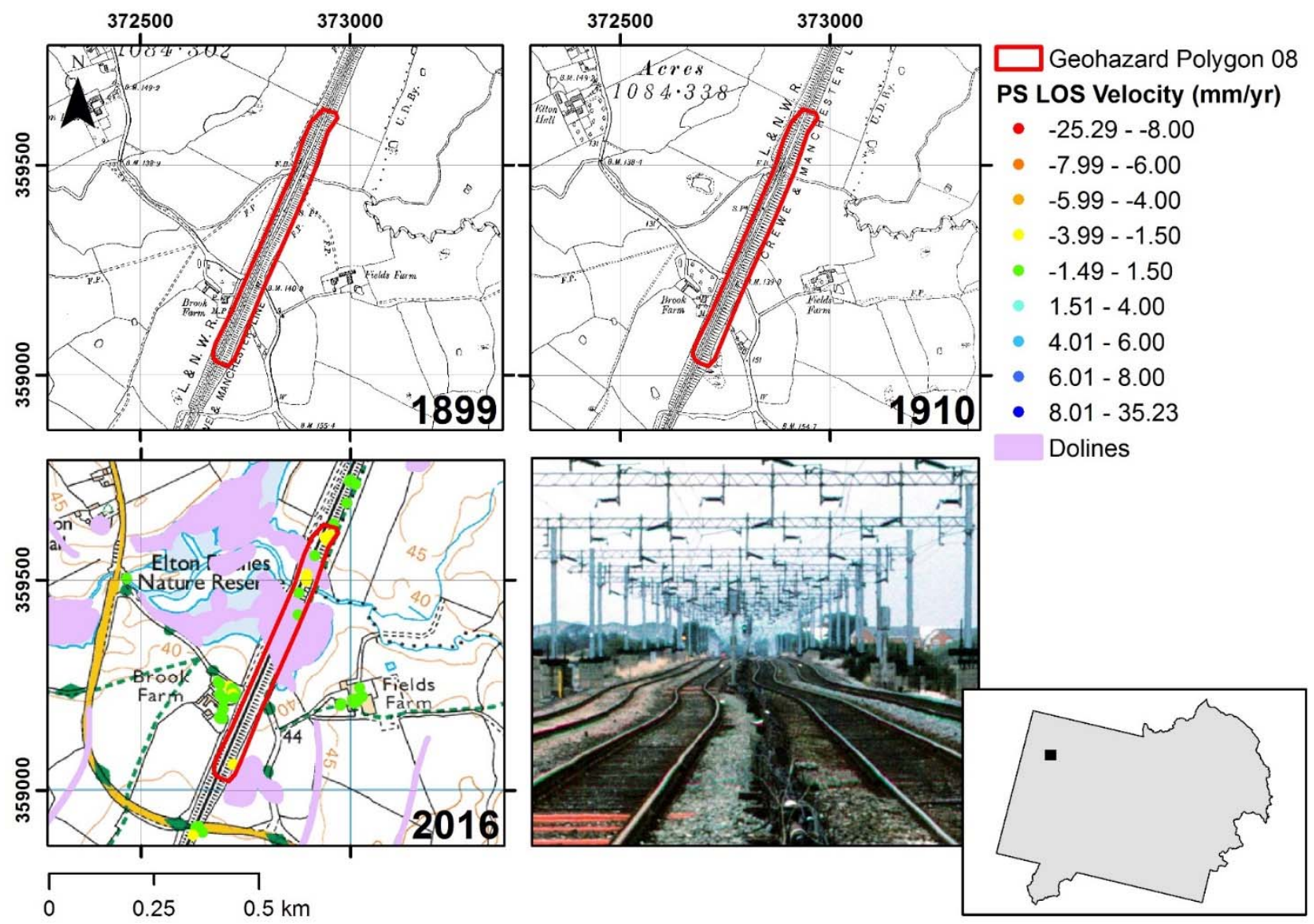

Figure 8. Average Persistent Scatterer (PS) Line of Sight (LOS) motion velocities for dissolution-related ground instability (Geohazard Polygon 08) in the Stoke-on-Trent area. The area of ground instability corresponds to mapped doline extents (BGS Karst Database) and distortion of the rail network (photo taken in 1996). Historic Ordnance Survey maps demonstrate the expansion of open water areas (potential dissolution sites) within the vicinity. Contains Ordnance Survey data (C) Crown Copyright and database rights 2017. Ordnance Survey Licence no. 100021290.

Polygon 14 represents 167 landslides (Figure 5) mapped by BGS using a combination of field campaigns and 3D topographic visualisation (Evans et al., 2013). The landslides are located in regions with increased gradients, being predominantly associated with steep terrain and incised valleys in the north-east of the area and along the eastern edge of the Cheshire basin and in association with drainage channels in the central and eastern portions. Instability is present on ground underlain by the Millstone Grit Group, Pennine Lower Coal Measures Formation and South Wales Lower Coal Measures Formation (Undifferentiated), Bowland High Group and Craven Group (Undifferentiated) and Warwickshire Group. The landslides are typically bedrock controlled with some shallow failures occurring in Devensian Till and artificial ground. Landsliding mechanisms evident in the area include flows, falls, topples and slides (Crofts, 1990; Rees \& Clark, 1992). A range of causal mechanisms have been identified including susceptible lithologies, stream incision (Howard, 1991) and artificial undercutting (Early \& Skempton, 1972).

Persistent scatterer density for polygon 14 is the lowest encountered in the study area with only 38 PS present (Table 2; Figure 9). This may occur for a number of reasons: 
- Several of the mapped landslides lie outside the area in which PSI data is available.

- The landslides typically occur in more rural areas where fewer reflectors are present.

- The identification of landslide deposits is based upon morphological characteristics and not necessarily on the observation of motion. This allows the mapping of older, less active landslides still visible in the landscape as well as those displaying instability at the time of survey. The older and/or more stable landslides would not be expected to display ground motion detectable by PS.

- Where landslides fail rapidly, ground motion is likely to be greater than the maximum potential motion that PSI techniques can estimate before encountering phase unwrapping problems.

- The satellite orbit inclination and sensor look angle favour detection of vertical movement over downslope motion, the latter being typical for landslides.
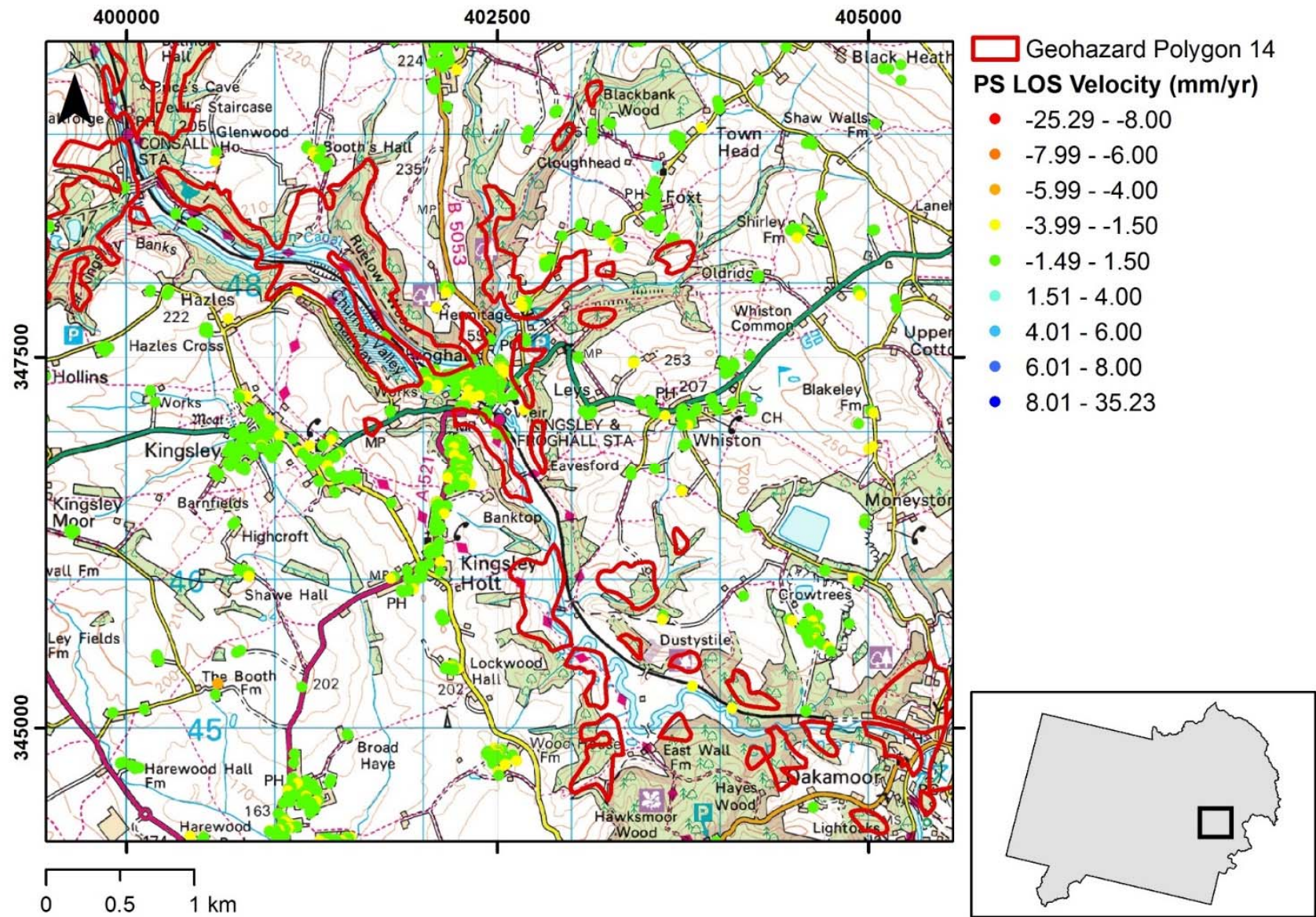

Figure 9. Landslides in the Stoke-on-Trent study area (a sub-set of Geohazard Polygon 14) and average Persistent Scatterer (PS) Line of Sight (LOS) motion velocities in the vicinity. Note that very few PS lie within the landslide areas. Contains Ordnance Survey data (C) Crown Copyright and database rights 2017. Ordnance Survey Licence no. 100021290.

\subsection{Methodological considerations}

The PanGeo project identified geohazards from PSI and geospatial data. The digitised geohazard polygons are subject to the specific temporal references, spatial scales and resolutions of the data. The mapping presented above, therefore, predominantly represents geohazards affecting the study area between 1992 and 2003 (the PS data time 
period). The landslide polygon is less constrained by this timespan as PS data was not the main source. The project results do not claim to be an exhaustive indication of all geohazards affecting the area. Indeed, different geohazards may operate in different timespans and at different points in the study area; changes in the direction of motion with time having been observed in other areas (e.g. Banton et al., 2013).

Geohazard susceptibility mapping has been undertaken by the BGS: GeoSure dataset (http://www.bgs.ac.uk/products/geosure/home.html). Developed at a scale of 1:50 000, this provides information about potential natural ground movement resulting from collapsible deposits, compressible ground, landslides, running sand, shrink-swell and soluble rocks. Susceptibility to each of these six geohazards is rated using an A (lowest) to $E$ (highest) classification (Booth et al., 2010). A comparison of the mapped geohazard polygons with the BGS GeoSure dataset suggests that the PanGeo methodology may underestimate motion from ground dissolution (Figure 10). This apparent discrepancy is likely to result for three reasons. Firstly, as discussed above, relatively rapid movements are likely to be less well represented by PS data. Secondly, PS density in this predominantly rural area is relatively low (Figure 4). Thirdly, the potential dissolution modelled by GeoSure has not, at the present time, taken place. The BGS is currently developing a National Karst Database (Cooper, Farrant \& Price, 2011) which will allow further examination of this. Use of GeoSure susceptibility mapping in conjunction with the PanGeo data for Stoke-on-Trent is, therefore, recommended to capture an enhanced suite of observed and potential geohazards affecting the area. 


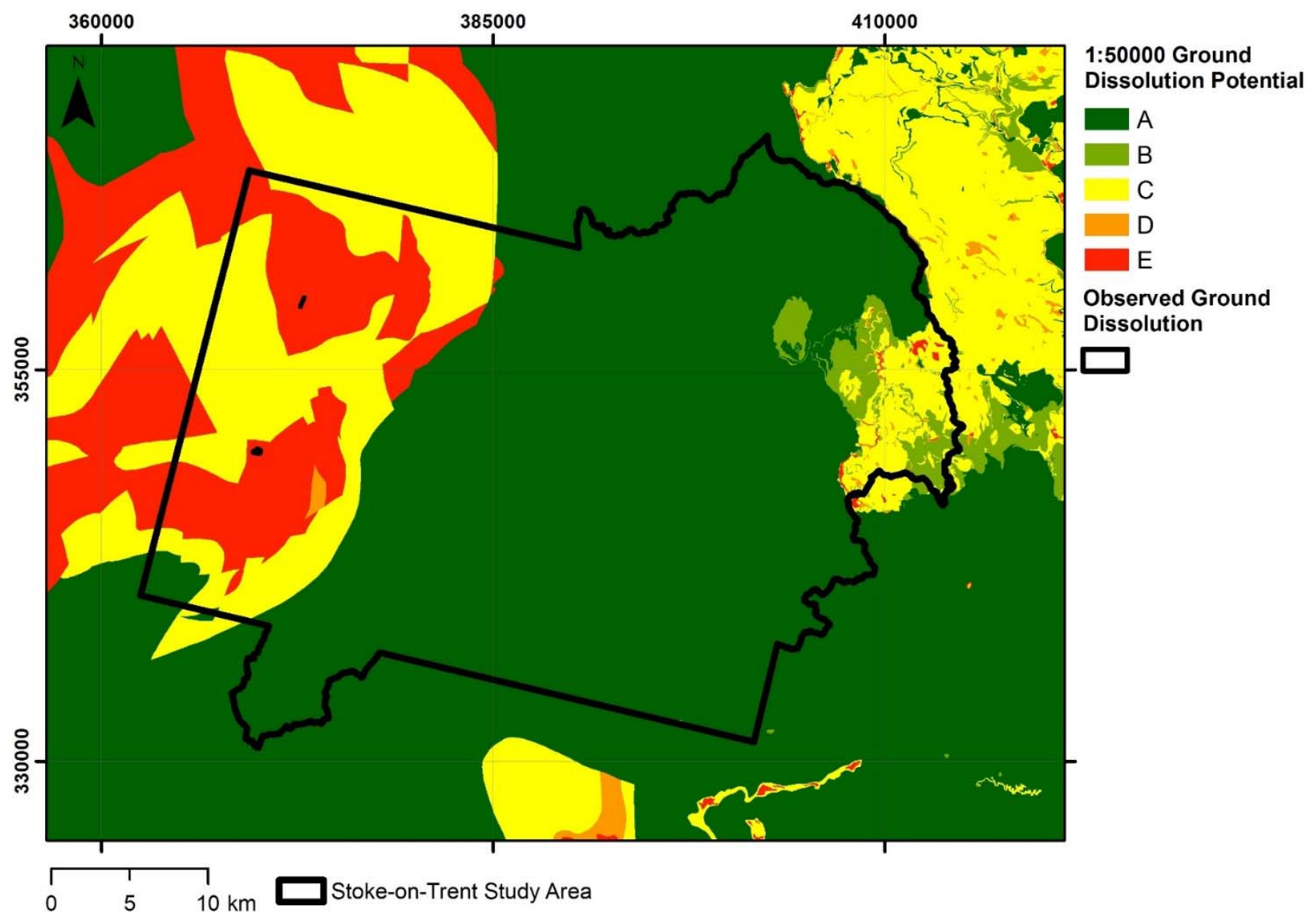

Figure 10. Dissolution potential (from BGS GeoSure data) and observed ground dissolution (Geohazard polygons 08 and 12) within the Stoke-on-Trent study area. Categories A to E represent increasing potential for ground dissolution.

Rapidity of ground motion may also account for the variation in spatial density of PS points found within the large areas of uplift (Polygon 01; Figure 6) and subsidence (polygons 03 and 06; Figure 11). Typically, these areas show a higher density of points towards the edges of the motion feature and a sparser density of points in the centre. Whilst the main control to the density of points is usually the presence of suitable reflectors, in these cases ground motion rate may also contribute, i.e. the ground motion having reached a rate which is too fast for InSAR to resolve. Where this is the case any identified points will have been discounted by the processing methodology. 


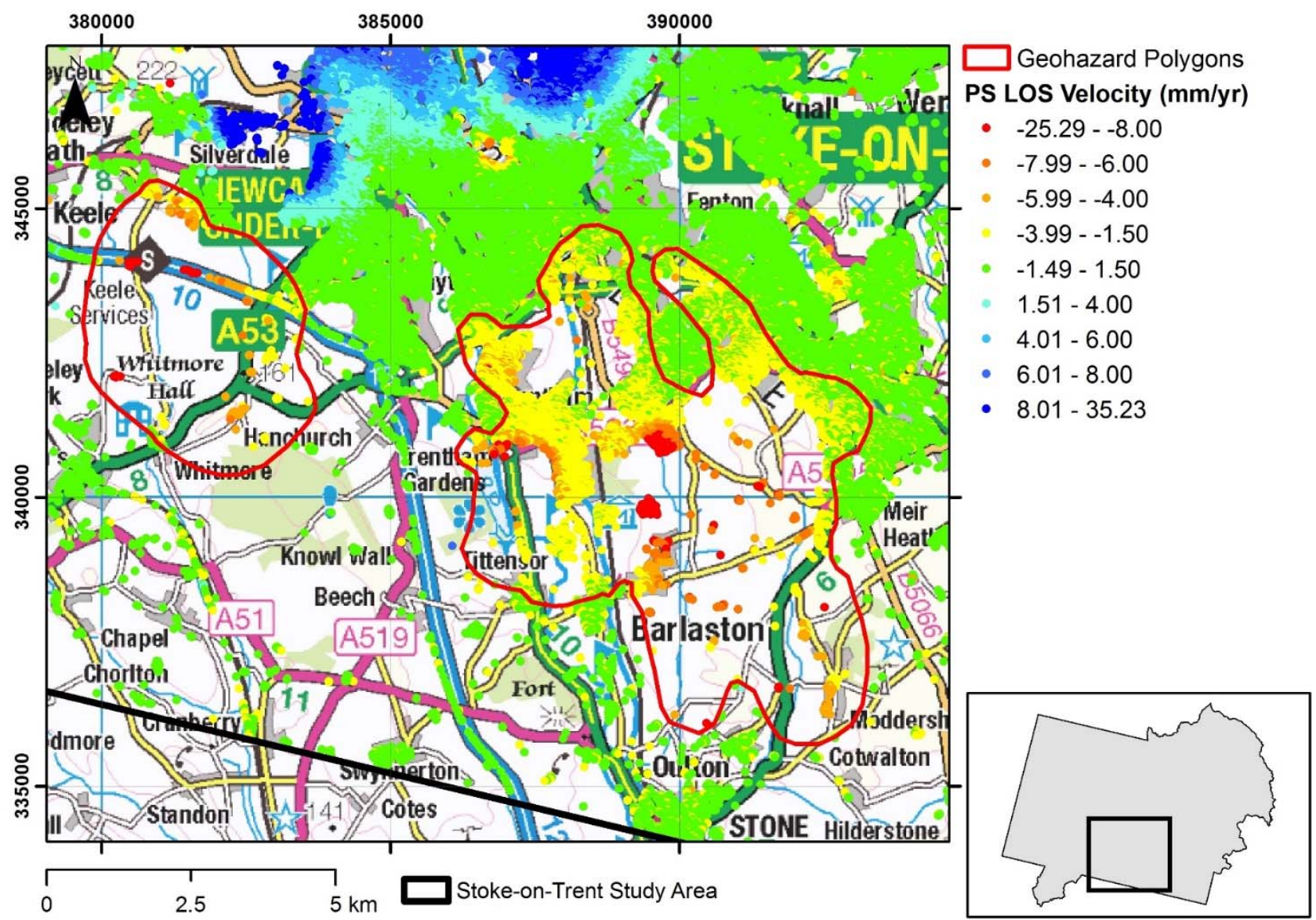

Figure 11. Average Persistent Scatterer (PS) Line of Sight (LOS) motion velocities for miningrelated instability (Geohazard Polygon 03, east and Geohazard Polygon 06, west) in the Stoke-on-Trent study area. Contains Ordnance Survey data (C) Crown Copyright and database rights 2017. Ordnance Survey Licence no. 100021290.

\section{Conclusions}

An increasing population density, high degree of anthropogenic activity and changing weather conditions combine to make UK geohazards research paramount. Motion data derived from satellite SAR imagery has proved invaluable for characterising hazardous ground instability from a range of processes across large areas. The current study employed a combined approach using PSI and supporting geospatial data to identify areas of ground motion in urban and rural areas of Stoke-on-Trent, UK. Forming part of the PanGeo project, 14 areas of subsidence, uplift and/or downslope ground movement were identified. These were attributed to a range of natural and anthropogenically-induced hazards, including landslides, dissolution, mining activity and artificial ground. A peak PS velocity towards the satellite of $35.23 \mathrm{~mm} / \mathrm{yr}$ was observed along with $22.57 \mathrm{~mm} / \mathrm{yr}$ away from the satellite sensor.

PS densities and standard deviations varied across the area with land use providing a significant influence. The more rural land uses were affected by temporal decorrelation and strong variations of interferometric phase so reducing reflector availability. This can hinder the identification of geohazards such as landslides and dissolution. Rapid motions such as some forms of landsliding, ground dissolution, mine collapse and fault reactivation are also likely to be overlooked by the PSI technique as a result of phase unwrapping problems. In 
these instances, the supporting geospatial data proves invaluable in recognising the instability. As with all interpretations, the digitised geohazard polygons are subject to the specific temporal references, spatial scales and resolutions of the datasets used. It is recommended, therefore, that the project results are analysed in conjunction with BGS GeoSure geohazard susceptibility mapping to capture an enhanced suite of both observed and potential geohazards affecting the area.

\section{Acknowledgements}

The PanGeo project was funded by the EU FP7 SPACE Programme, grant agreement no. 262371. ERS-1/2 SAR data was provided by Tele-Rilevamento Europa. Details of rightholders and terms of licence can be found at www.pangeoproject.eu. This paper is published with the permission of the Executive Director of BGS, NERC. The authors are grateful to Dr Tom Dijkstra (BGS) for assistance with the drafting of this paper and Dr Anthony Cooper (BGS Honorary Research Associate) for supplying the photograph in Figure 8.

\section{References}

Banton, C., Bateson, L., McCormack, H., Holley, R., Watson, I., Burren, R., Lawrence, D., Cigna, F., 2013. Monitoring post closure large scale surface deformation in mining areas, Mine Closure 2013, Eighth International Conference on Mine Closure. Australian Centre for Geomechanics, Perth, Eden Project, Cornwall, UK.

Bateson, L., Cuevas, M., Crosetto, M., Cigna, F., Schijf, M., Evans, H. 2012. PANGEO: enabling access to geological information in support of GMES: deliverable 3.5 production manual. Version 1.

European Commission, 104pp. BGS report OR/12/053.

Bateson, L., Cigna, F., Boon, D., Sowter, A. 2015. The application of the Intermittent SBAS (ISBAS) InSAR method to the South Wales Coalfield, UK. International Journal of Applied Earth Observation and Geoinformation, 34: 249-257.

Booth, K. A., Diaz Doce, D., Harrison, M., Wildman, G. 2010. User guide for the British Geological Survey GeoSure dataset. BGS report OR/10/066.

Capes, R., Teeuw, R. 2017. On safe ground? Analysis of European urban geohazards using satellite radar interferometry. International Journal of Applied Earth Observation and Geoinformation, 58: 7485.

Cigna, F., Bianchini, S., Casagli, N., 2013a. How to assess landslide activity and intensity with Persistent Scatterer Interferometry (PSI): The PSI-based matrix approach. Landslides, 10(3): 267-283.

Cigna, F., Bateson, L., Jordan, C., Dashwood, C., 2013b. Nationwide monitoring of geohazards in Great Britain with In-SAR: Feasibility mapping based on ERS-1/2 and ENVISAT imagery. 2013 IEEE International Geoscience and Remote Sensing Symposium (IGARSS 2013), pp. 672-675.

Cigna, F., Jordan, H., Bateson, L., McCormack, H., Roberts, C. 2014. Natural and anthropogenic geohazards in Greater London observed from geological and ERS-1/2 and ENVISAT persistent scatterers ground motion data: results from the EC FP7-SPACE PanGeo project. Pure and Applied Geophysics. 1-31. DOI 10.1007/s00024-014-0927-3.

Cooper, A. H. 2002. Halite karst geohazards (natural and man-made) in the United Kingdom. Environmental Geology, 42: 505-51. 
Cooper, A. H., Farrant, A. R., Price, S. J. 2011. The use of karst geomorphology for planning, hazard avoidance and development in Great Britain. Geomorphology, 134 (1-2): 118-131.

10.1016/j.geomorph.2011.06.004.

Crofts, R. G. 1990. Geology of the Kidsgrove District 1:10 000 Sheet SJ 85 SW Part of 1:50 000 Sheet 123 (Stoke-on-Trent). BGS Technical Report WA/90/07.

Crosetto, M., Monserrat, O., Adam, N., Parizzi, A., Bremmer, C., Dortland, S., Hanssen, R.F., Van Leijen, F.J. 2008. Validation of existing processing chains in TerraFirma stage 2-Final Report. GMES TERRAFIRMA ESRIN/Contract no. 19366/05/IE. (15 pp.).

Cuenca. M. C., Hooper, A. J., Hanssen, R. F. 2013. Surface deformation induced by water influx in the abandoned coal mines in Limberg, The Netherlands observed by satellite radar interferometry. Journal of Applied Geophysics, 88: 1-11.

Culshaw, M., Tragheim, D., Bateson, L., Donnelly, L. 2006. Measurement of ground movements in Stoke-on-Trent (UK) using radar interferometry. In: Culshaw, M., Reeves, H., Jefferson, I., Spink, S. (Eds.), 10th Congress of the International Association for Engineering Geology and the Environment, IAEG2006. Geological Society, London, Nottingham, UK, pp. 1-10.

Early, K. R., Skempton, A. W. 1972. Investigations of the landslide at Walton's Wood, Staffordshire. Quarterly Journal of Engineering Geology, 5: 19-41.

European Environment Agency (EEA), 2010, GMES Urban Atlas. Available at: http://www.eea.europa.eu/data-and-maps/data/urban-atlas._Accessed 04/03/2015.

Evans, H., Pennington, C., Jordan, C., Foster, C. 2013. Mapping a Nation's Landslides: A Novel MultiStage Methodology. In: Margottini, C., Canuti, P., Sassa, K. (Eds.), Landslide Science and Practice. Springer Berlin Heidelberg, pp. 21-27.

Ferretti, A., Basilico, M., Novali, F., Prati, C. 2004. Possibile utilizzo di dati radar satellitari per individuazione e monitoraggio di fenomini di sinkholes. In: Nisio, S., Panetta, S., Vita, L. (Eds.), Stato dell'arte sullo studio dei fenomeni di sinkholes e ruolo delle amministrazioni statali e locali nel governo del territorio, APAT, Roma (2004), pp. 331-340.

Howard, A. S. 1991. Geology of the Werrington District 1:10 000 Sheet SJ 94 NW Part of Part of 1:50 000 Sheet 123 (Stoke-on-Trent). BGS Technical Report WA/90/09.

Jones, L. D., Terrington, R. 2011. Modelling volume change potential in the London Clay. Quarterly Journal of Engineering Geology and Hydrogeology, 44: 109-122.

Jordan, H., Cigna, F., Bateson, L. 2013. GeoHazard Description for Stoke-On-Trent, Version 1.0. pp 122. Available at: http://www.pangeoproject.eu/pdfs/english/stoke/Geohazard-Descriptionstoke.pdf. Accessed 12/05/2015.

Office for National Statistics. 2015. Neighbourhood Statistics: Stoke-on-Trent. Available at: http://www.neighbourhood.statistics.gov.uk/dissemination/LeadTableView.do?a $=5 \& b=6275263 \& c=$ stoke-on-

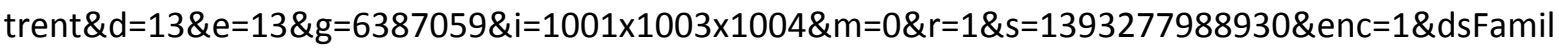
yld $=2477$. Accessed 14/10/15. 
Pennington, C. V. L., Harrison, A. M. 2013. 2012 - a landslide year? GeoScientist magazine, Geological Society of London 23: 10-15.

Rees, J. G., Clark, M. C. 1992. Geology of the Tunstall District 1:10 000 Sheet SJ 85 SE Part of the 1:50 000 Sheet 123 (Stoke-on-Trent). BGS Technical Report WA/90/08.

Rees, J. G., Wilson, A. A. 1998. Geology of the country around Stoke-On-Trent. British Geological Survey Memoir for the 1:50 000 Geological Sheet 123 (England and Wales). London: HMSO for the British Geological Survey.

Sowter, A., Bateson, L., Strange, P., Ambrose, K., Syafiudin, M. 2013. DInSAR estimation of land motion using intermittent coherence with application to the South Derbyshire and Leicestershire coalfield. Remote Sensing Letters, 4(10): 979-987.

Worsley, P. 2008. Pleistocene and Flandrian Natural Rock Subsidence at Arclid Green, Sandbach, Cheshire. Mercian Geologist, 17(1): 11-18.

Wasowsk, J., Bovenga, F. 2015. Investigating landslides and unstable slopes with satellite Multi Temporal Interferometry: current issues and future perspectives. Engineering Geology, 174: 103138.

Zhu, L., Gong, H., Teatini, P., Li, X., Wang, R., Chen, B., Dai, Z. 2015. Land Subsidence due to groundwater withdrawal in the northern Beijing plain, China, Engineering Geology (2015), doi:10.1016/j.enggeo.2015.04.020. 
